\title{
GENERALIZED PWM TECHNIQUE FOR DUAL INVERTER FED INDUCTION MOTOR DRIVE
}

\author{
M. HARSHAVARDHAN REDDY*, T. BRAHMANANDA REDDY*, B. RAVINDRANATH REDDY** \\ M. SURYA KALAVATHI ${ }^{* *}$ \\ *Department of Electrical and Electronics Engineering, G. Pulla Reddy Engineering College (Autonomous) \\ Kurnool, Andhra Pradesh, India, e-mail: maramreddyharsha@gmail.com, tbnr@rediffmail.com \\ ${ }^{* *}$ Department of Electrical and Electronics Engineering, JNTUH, Hyderabad, Andhra Pradesh, India
}

\begin{abstract}
This paper presents a simplified Generalized Pulse Width Modulation (GPWM) algorithm to obtain various continuous and discontinuous PWM algorithms for a four-level inverter topology. The proposed four-level inverter is achieved by feeding the induction motor from both ends by a three-level cascade inverter from one side and by two-level inverter from other side. The proposed inverter configuration is capable to produce an output voltage of two-level, three-level and four-level in entire modulation range. In the proposed inverter topology neutral point fluctuations are absent and neutral clamping diodes are absent. With the application of various discontinuous PWM algorithms to the proposed inverter topology the switching losses are reduced when compared with continuous PWM algorithm. The simulation analyses are carried out in MATLAB/simulink environment and the results are presented.
\end{abstract}

Keywords: Cascade inverter, GPWM, open end winding induction motor, SVPWM

\section{INTRODUCTION}

Voltage Source Inverters (VSI) are getting popularized in adjustable speed drive applications. To control the output voltage and output frequency of VSI, the pulse width modulation (PWM) techniques are employed. The switching fashion employed in PWM techniques reduces harmonics in the output voltage. Based on switching fashion different PWM techniques are proposed in literature [1-5]. Among Various PWM techniques space vector pulse width modulation (SVPWM) technique proposed in [4-5] gives superior performance for a voltage source inverter. SVPWM discussed in [4], in a given sampling time $\left(\mathrm{T}_{\mathrm{s}}\right)$ the switching times for which active voltage vectors and zero voltage vectors times are given by (1). In conventional SVPWM algorithm, the zero vector time $\left(\mathrm{T}_{\mathrm{z}}\right)$ is divided equally among the two possible zero states. The calculation of switching times $\left(T_{1}, T_{2}, T_{z}\right)$ require angular information $(\alpha)$ and magnitude of reference voltage $\left(\mathrm{V}_{\text {ref }}\right)$ at each instant, which makes the SVPWM algorithm complex.

$$
\begin{aligned}
& T_{1}=\frac{2 \sqrt{3}}{\pi} M_{i} \sin \left(60^{0}-\alpha\right) T_{s} \\
& T_{2}=\frac{2 \sqrt{3}}{\pi} M_{i} \sin (\alpha) T_{s} \\
& T_{Z}=T_{s}-T_{1}-T_{2}
\end{aligned}
$$

where $\mathrm{M}_{i}$ is the modulation index $M_{i}=\frac{\pi V_{r e f}}{2 V_{d c}}$.

In [5], the authors proposed a simplified algorithm where no need to calculate the angular information by using the concept of imaginary switching times. Along with simplification of algorithm, various discontinuous PWM algorithms have been presented in [7-8] by unequal division of zero state times.
However, the two-level inverters produce more harmonic distortion. In two-level inverter topologies as switching frequency increases the harmonic content in line current gets reduced. In order to have low harmonic content at low switching frequency multilevel inverter topologies are employed. Different multilevel inverter topologies are presented in literature [9-10]. Conventional Multilevel inverter topologies like diode clamped and H-bridge topologies discussed in [9-11] require clamping diodes, separate DC-link voltages sources for their operation. Multilevel inverter topologies have the drawbacks of neutral point fluctuations and complexity increases as number of levels increases. To overcome these drawbacks and reduce complexity cascade and dual inverter topologies are presented in literature. As multilevel inverter topologies can synthesis output voltage waveform from small individual voltage sources. Two two-level inverters are cascaded to generated three level output voltage, this configuration is called cascade inverter topology proposed in literature [12]. Similarly two two-level inverter topologies feed the load from both ends called dual inverter configuration is proposed in literature [13]. Both cascade and dual inverter topologies are combined as shown in Fig.1 to generate four-level output voltage [14-15].

In this paper, a simplified and more generalized approach is presented to generate all possible continuous and discontinuous PWM (DPWM) signals by adding a zero sequence voltage to the commanded reference signals. The harmonic content in the output voltage is low at low switching frequency by employing proposed topology. But the switching losses can also be reduced by employing various DPWM algorithms.

\section{PROPOSED INVERTER TOPOLOGY}

The proposed circuit topology is obtained by feeding induction motor from both ends by three-level cascade inverter and two-level inverter as shown in Fig. 1. 


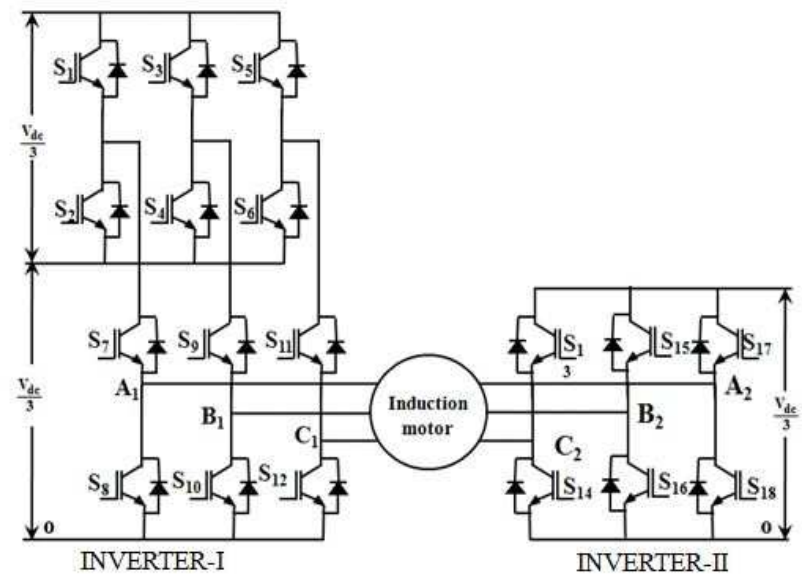

Fig. 1 Proposed inverter topology

$\mathrm{V}_{\mathrm{A} 10}, \mathrm{~V}_{\mathrm{B} 10}, \mathrm{~V}_{\mathrm{Clo}}$ represents the pole voltage of inverterI. As two inverters are cascaded inverter-I can generate three level output voltage. $\mathrm{V}_{\mathrm{A} 20^{\prime}}, \mathrm{V}_{\mathrm{B} 20^{\prime}}, \mathrm{V}_{\mathrm{C} 20^{\prime}}$ are the pole voltages of Inverter-II. $\mathrm{V}_{\mathrm{A} 1 \mathrm{~A} 2}, \mathrm{~V}_{\mathrm{B} 1 \mathrm{~B} 2}, \mathrm{~V}_{\mathrm{C} 1 \mathrm{C} 2}$ are the effective phase voltages. The combined pole voltage of proposed multi level inverter are given by

$$
\begin{aligned}
& V_{A}=V_{A 1 O}-V_{A 2 O} \\
& V_{B}=V_{B 1 O}-V_{B 2 O} \\
& V_{C}=V_{C 1 O}-V_{C 2 O}
\end{aligned}
$$

To control the output voltage and frequency of proposed inverter topology, various carrier based PWM algorithms are presented in this paper. In multilevel inverter topologies to generate $\mathrm{N}$-level output voltage $(\mathrm{N}-$ 1) level shifting triangles are required. So for the proposed topology, to generate four-level output, three level shifting triangles are required. The level shifting triangles are divided into three regions R1, R2 and R3 as shown in Fig. 2 .

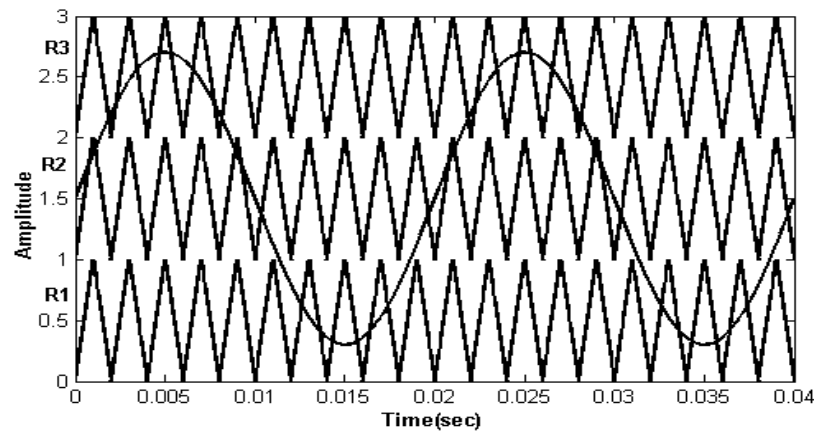

Fig. 2 Different regions in carrier comparison approach

Let us consider $\mathrm{Vc}$ be the amplitude of triangle wave and $\mathrm{V}_{\mathrm{m}}$ be the amplitude of reference wave. Now we define modulation index as

$M_{i}=\frac{V m}{V_{C}(N-1)}$

If the modulation signal lies within the region $\mathrm{R}_{1}$ as shown in Fig. 3, only Inverter-I is in operation and inverter-II is clamped.

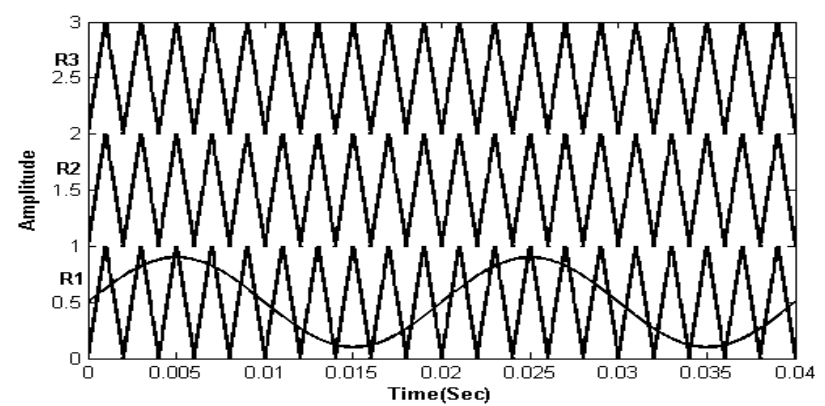

Fig. 3 Modulation signal position during two-level operation

All the phases of inverter-I produces a two-level output voltage $\left(\mathrm{V}_{\mathrm{dc}} / 3\right.$ or $\left.2 \mathrm{~V}_{\mathrm{dc}} / 3\right)$ by operating switches $\left(\mathrm{S}_{1}, \mathrm{~S}_{3}, \mathrm{~S}_{5}\right)$ and $\left(\mathrm{S}_{2}, \mathrm{~S}_{4}, \mathrm{~S}_{6}\right)$ and clamping the switches $\left(\mathrm{S}_{7}\right.$, $\left.\mathrm{S}_{9}, \mathrm{~S}_{11}\right)$ to a voltage of positive voltage of $\mathrm{V}_{\mathrm{dc}} / 3$. The corresponding pole voltages, phase voltages and line voltages are shown in Fig. 4.
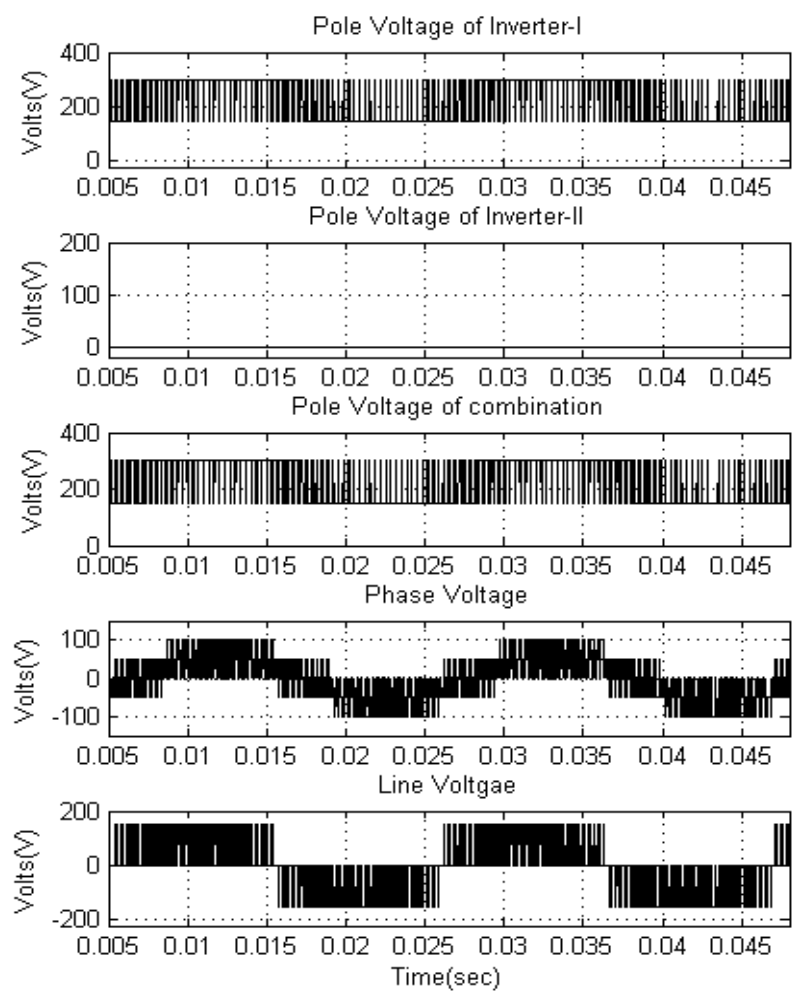

Fig. 4 Voltage plots during two-level operation by using the SPWM algorithm

As the combined pole voltage of the proposed inverter produces two-level output the mode of operation is called as two-level operation. If the modulating wave is present in both regions $R_{1}$ and $R_{2}$ as shown in Fig. 5, all the switches in inverter-I operate continuously to produce output voltage. When switches $\left(\mathrm{S}_{1}, \mathrm{~S}_{3}, \mathrm{~S}_{5}\right)$ and $\left(\mathrm{S}_{7}, \mathrm{~S}_{9}, \mathrm{~S}_{11}\right)$ are ON Inverter-I produces an output voltage of $\left(2 \mathrm{~V}_{\mathrm{dc}} / 3\right)$. When $\left(\mathrm{S}_{2}, \mathrm{~S}_{4}, \mathrm{~S}_{6}\right)$ and $\left(\mathrm{S}_{7}, \mathrm{~S}_{9}, \mathrm{~S}_{11}\right)$ are $\mathrm{ON}$ inverter-I produces an output voltage of $\left(\mathrm{V}_{\mathrm{dc}} / 3\right)$. When $\left(\mathrm{S}_{8}, \mathrm{~S}_{10}, \mathrm{~S}_{12}\right)$ are $\mathrm{ON}$, inverter-I produces zero output voltage. Similarly, all the switches in inverter-II are clamped to produce a zero voltage. 


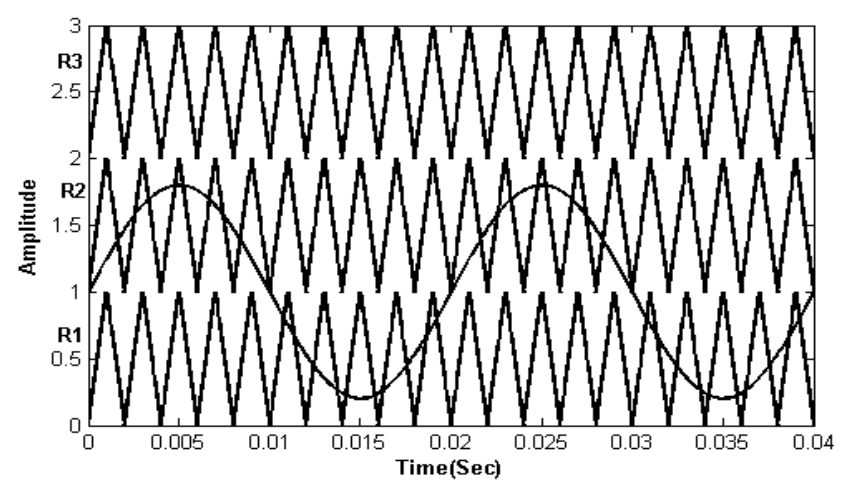

Fig. 5 Modulating signal during three-level operation

Therefore the effective pole voltage of proposed multilevel inverter contains three levels $\left(2 \mathrm{~V}_{\mathrm{dc}} / 3, \mathrm{~V}_{\mathrm{dc}} / 3,0\right)$. So this mode of operation is known as three-level mode of operation. The corresponding pole voltages, phase voltages and line voltages are shown in Fig. 6 during three-level mode of operation.
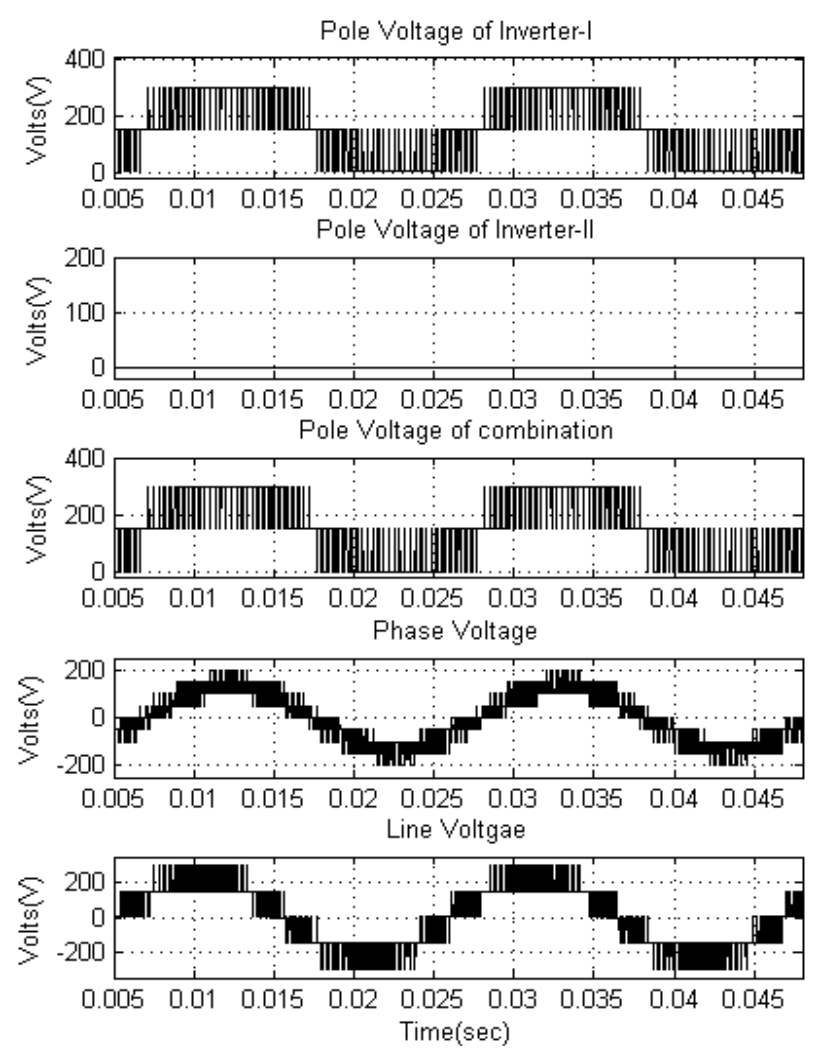

Fig. 6 Voltage plots during three-level operation by using the SPWM algorithm

When the modulating signal is present in all the three regions as shown in Fig. 2 all the switches in proposed multilevel inverter topology operate continuously to produce an output voltage. During this mode of operation inverter-I produce three-level output voltage and inverterII produce two-level output voltage. The corresponding pole voltages of inverter-I and inverter-II during this mode of operation are given in Table-1 along with their effective pole voltages. Thus a three phase induction motor attains four-level output voltages. So the combined effective pole voltage of proposed multilevel inverter produces fourlevel output voltage as shown in Fig. 7. The corresponding pole voltages, phase voltages and line voltages during four level operations are shown in Fig. 7.
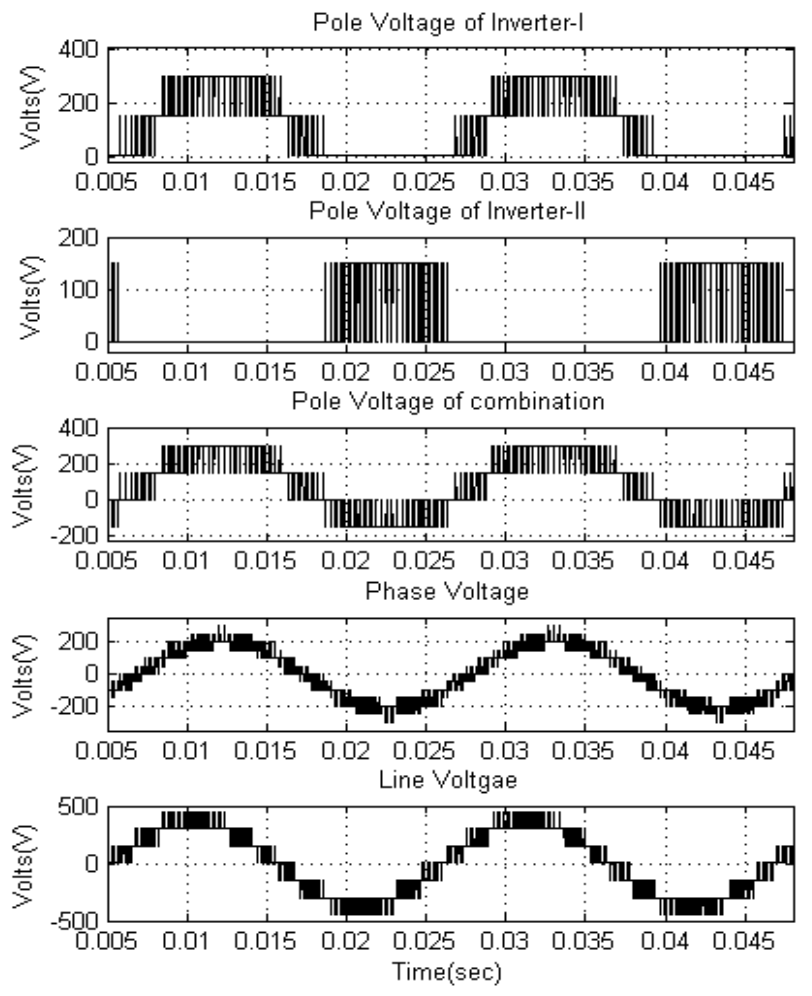

Fig. 7 Voltage plots during four-level operation by using the SPWM algorithm

Table 1 Different voltages during four-level operation

\begin{tabular}{|c|c|c|}
\hline $\begin{array}{l}\text { Pole voltage } \\
\text { of inverter-I } \\
\mathrm{V}_{\mathrm{a} 10}\end{array}$ & $\begin{array}{l}\text { Pole voltage } \\
\text { of Inverter-II } \\
\mathrm{V}_{\mathrm{a} 20}\end{array}$ & $\begin{array}{l}\text { Effective } \\
\text { pole voltage } \\
\mathrm{V}_{\mathrm{a}}\end{array}$ \\
\hline 0 & 0 & 0 \\
\hline 0 & $\mathrm{~V}_{\mathrm{dc}} / 3$ & $-\mathrm{V}_{\mathrm{dc}} / 3$ \\
\hline $\mathrm{V}_{\mathrm{dc}} / 3$ & 0 & $+\mathrm{V}_{\mathrm{dc}} / 3$ \\
\hline $\mathrm{V}_{\mathrm{dc}} / 3$ & $\mathrm{~V}_{\mathrm{dc}} / 3$ & 0 \\
\hline $2 \mathrm{~V}_{\mathrm{dc}} / 3$ & 0 & $+2 \mathrm{~V}_{\mathrm{dc}} / 3$ \\
\hline $2 \mathrm{~V}_{\mathrm{dc}} / 3$ & $\mathrm{~V}_{\mathrm{dc}} / 3$ & $+\mathrm{V}_{\mathrm{dc}} / 3$ \\
\hline
\end{tabular}

The advantage of proposed control strategy for proposed multilevel inverter topology is that all the four levels of operation can be achieved in entire modulation index (from 0 to 1 ).

\section{PROPOSED GPWM ALGORITHM}

Assume two set of instantaneous phase voltages as given in (4) and (5).

$V_{a n}=V_{m} \cos (\omega t)$

$V_{b n}=V_{m} \cos (\omega t-120)$

$V_{c n}=V_{m} \cos (\omega t-240)$

$V_{a x}=V_{m} \cos (\omega t)$

$V_{b x}=V_{m} \cos (\omega t-120)$ 
As the potential $\mathrm{O}$ and $\mathrm{O}^{\prime}$ are isolated, in proposed GPWM algorithm, the modulating waves are generated by simply adding zero sequence voltage to the instantaneous phase voltages as given in (6).

$V_{\text {in }}^{*}=V_{\text {in }}+V_{z s}, \quad i=a, b, c$

Where $V_{z s}=\frac{V d c}{2}\left(2 a_{0}-1\right)-a_{0} V_{\max }+\left(a_{0}-1\right)$

$\mathrm{V}_{\mathrm{zS}}$ is known as zero sequence voltage.

$\mathrm{V}_{\max }$ is the maximum of $\mathrm{V}_{\mathrm{an}}, \mathrm{V}_{\mathrm{bn}}, \mathrm{V}_{\mathrm{cn}}$ and $\mathrm{V}_{\max , \mathrm{x}}$ is the maximum value of $\mathrm{V}_{\mathrm{ax}}, \mathrm{V}_{\mathrm{bx}}, \mathrm{V}_{\mathrm{cx}}$ in each sampling time interval. For the generation of various PWM algorithms, the variation of the constant is shown in Table- 2 and the corresponding modulating signals are shown in Fig. 8. From the Fig. 8, it can be observed that the SVPWM has continuous modulating waveform and hence gives continuous pulse pattern. Whereas, the modulating waves of discontinuous PWM (DPWM) algorithms clamp to either positive dc or negative dc bus for a duration of 120 degrees in each fundamental cycle. Hence, the switching losses can be reduced by $33.33 \%$.

Table $2 \mathrm{a}_{\mathrm{o}}$ value for various PWM algorithms

\begin{tabular}{|l|c|}
\hline $\begin{array}{l}\text { PWM } \\
\text { algorithm }\end{array}$ & $a_{o}$ \\
\hline SVPWM & 0.5 \\
\hline DPWMMIN & 0 \\
\hline DPWMMAX & 1 \\
\hline DPWM0 & $\begin{array}{l}V_{\max }+V_{\min }<0 \text { then } a_{0}=0 \\
V_{\max }+V_{\min } \geq 0 \text { then } a_{0}=1\end{array}$ \\
\hline DPWM1 & $V_{\max , x}+V_{\min , x} \geq 0$ then $a_{0}=1$ \\
& $V_{\max , x}+V_{\min , x}<0$ then $a_{0}=0$ \\
\hline DPWM2 & $V_{\max }+V_{\min }<0$ then $a_{0}=1$ \\
& $V_{\max }+V_{\min } \geq 0$ then $a_{0}=0$ \\
\hline DPWM3 & $V_{\max , x}+V_{\min , x}<0$ then $a_{0}=1$ \\
& $V_{\max , x}+V_{\min , x} \geq 0$ then $a_{0}=0$ \\
\hline
\end{tabular}
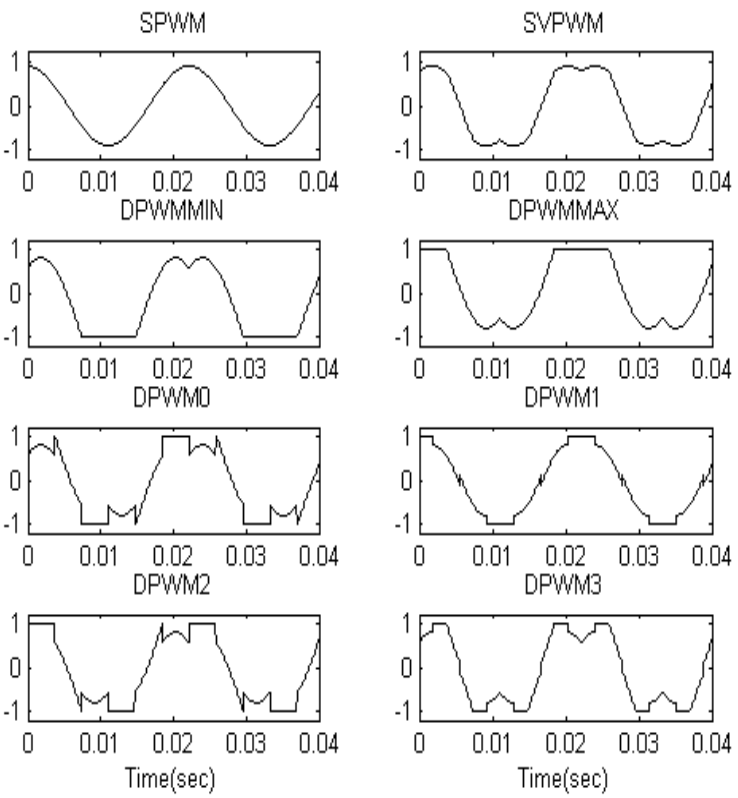

Fig. 8 Modulating signals of different PWM algorithms

\section{SIMULATION RESULTS AND DISCUSSION}

The characteristics of multilevel inverter topology with different PWM algorithms have been studied and analyzed in MATLAB/simulation environment for a three phase induction motor. The induction motor parameters used in the analysis and inverter parameters are given in Table-3. For the simulation studies, the switching frequency is taken as $3 \mathrm{kHz}$. Hence, the sampling time period (T) for is taken as $0.333 \mathrm{~ms}$. The simulation studies have been carried out for four-level operation. Hence, to achieve four -level operation, for a sampling time period of $\mathrm{T}$ inverter-I is switched for a period of $(2 \mathrm{~T} / 3)$ and inverter-II is switched for a period of $(T / 3)$. Moreover, when one inverter is switched other inverter is clamped. The operation of inverters for various PWM algorithms is as shown in Table-4. The simulation results for various PWM algorithms for a four-level operation are shown in from Fig. 9 to Fig. 15.

Table 3 Parameters and specifications of the Induction motor

\begin{tabular}{|l|l|l|l|}
\hline $\begin{array}{l}\text { Rated } \\
\text { speed }\end{array}$ & $1500 \mathrm{RPM}$ & $\begin{array}{l}\text { Rotor } \\
\text { resistance }\end{array}$ & $1.21 \Omega$ \\
\hline frequency & $50 \mathrm{HZ}$ & $\begin{array}{l}\text { Inverter input } \\
\text { DC Voltage }\end{array}$ & $450 \mathrm{~V}$ \\
\hline $\begin{array}{l}\text { Stator } \\
\text { resistance }\end{array}$ & $1.57 \Omega$ & $\begin{array}{l}\text { Mutual } \\
\text { inductance }\end{array}$ & $176 \mathrm{mH}$ \\
\hline $\begin{array}{l}\text { Stator } \\
\text { inductance }\end{array}$ & $183 \mathrm{mH}$ & $\begin{array}{l}\text { Rotor } \\
\text { inductance }\end{array}$ & $183 \mathrm{mH}$ \\
\hline
\end{tabular}

Table 4 Operation of inverters for various PWM algorithms

\begin{tabular}{|l|l|l|l|}
\hline $\begin{array}{l}\text { Type of } \\
\text { PWM }\end{array}$ & $\begin{array}{l}\text { Operation of } \\
\text { Inverter-I in } \\
2 \mathrm{~T} / 3 \text { time } \\
\text { period }\end{array}$ & $\begin{array}{l}\text { Operation of } \\
\text { Inverter-II in } \\
\mathrm{T} / 3 \text { time } \\
\text { period }\end{array}$ & Reason \\
\hline SPWM & $\begin{array}{l}\text { Continuous } \\
\text { switching } \\
\text { in2T/3 } \\
\text { period }\end{array}$ & $\begin{array}{l}\text { Continuous } \\
\text { switching in } \\
\text { T/3 period }\end{array}$ & $\begin{array}{l}\text { Continuous } \\
\text { modulating } \\
\text { waveform }\end{array}$ \\
\hline SVPWM & $\begin{array}{l}\text { Continuous } \\
\text { switching } \\
\text { in2T/3 } \\
\text { period }\end{array}$ & $\begin{array}{l}\text { Continuous } \\
\text { switching in } \\
\text { T/3 period }\end{array}$ & $\begin{array}{l}\text { Continuous } \\
\text { modulating } \\
\text { waveform }\end{array}$ \\
\hline DPWMMIN & $\begin{array}{l}\text { some time } \\
\text { duration in } \\
2 \mathrm{~T} / 3 \text { period }\end{array}$ & $\begin{array}{l}\text { Continuous } \\
\text { switching in } \\
\text { T/3 period }\end{array}$ & $\begin{array}{l}\text { As the } \\
\text { modulating } \\
\text { wave is } \\
\text { clamped to } \\
\text { negative dc } \\
\text { bus }\end{array}$ \\
\hline DPWMMAX & $\begin{array}{l}\text { Continuous } \\
\text { switching in } \\
2 \mathrm{~T} / 3 \text { period }\end{array}$ & $\begin{array}{l}\text { clamped for } \\
\text { some time } \\
\text { duration in } \\
\text { T/3 period }\end{array}$ & $\begin{array}{l}\text { As the } \\
\text { modulating } \\
\text { wave is } \\
\text { clamped to } \\
\text { positive dc bus }\end{array}$ \\
\hline DPWM0 & $\begin{array}{l}\text { clamped for } \\
\text { some time } \\
\text { duration in } \\
2 \mathrm{~T} / 3 \text { period }\end{array}$ & $\begin{array}{l}\text { clamped for } \\
\text { some time } \\
\text { duration in } \\
\text { T/3 period }\end{array}$ & $\begin{array}{l}\text { As the } \\
\text { modulating wave } \\
\text { is clamped to } \\
\text { both positive and } \\
\text { negative dc bus }\end{array}$ \\
\hline DPWM1
\end{tabular}


Pole Voltage of Inverter-I
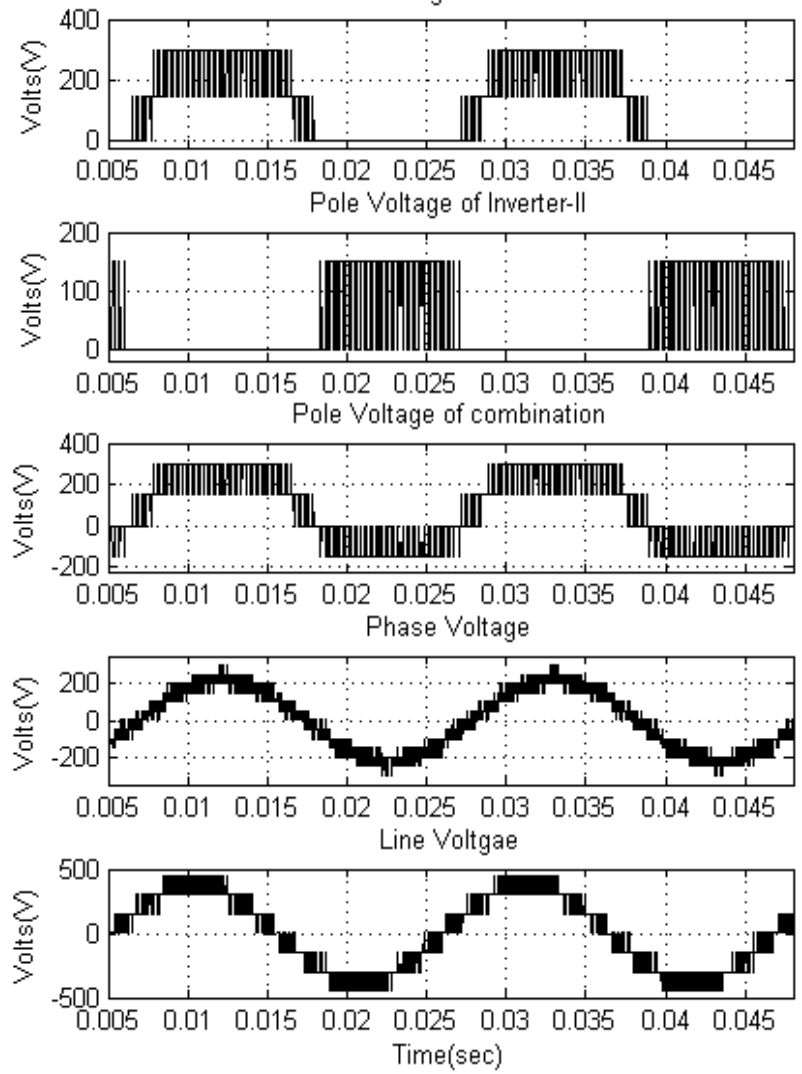

Fig. 9 Voltage plots with SVPWM algorithm during four-level operation

Pole Voltage of Inverter-I
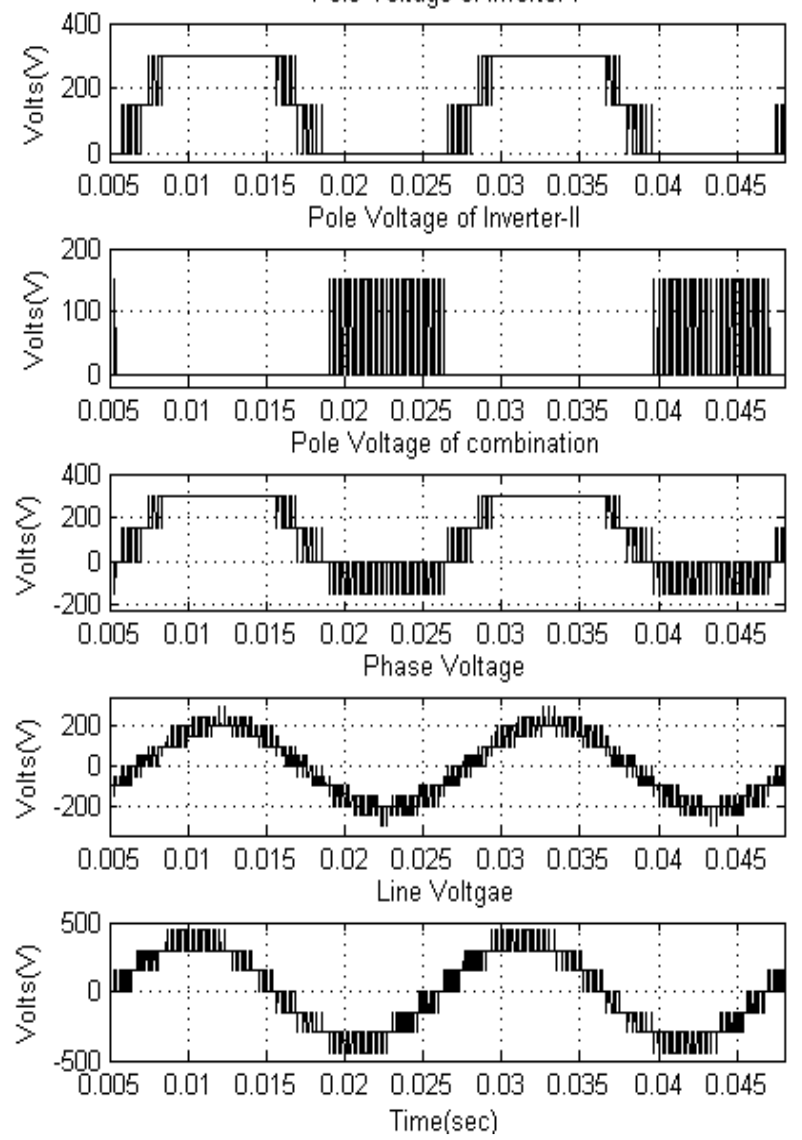

Fig.10 Voltage plots with DPWMMIN algorithm during fourlevel operation
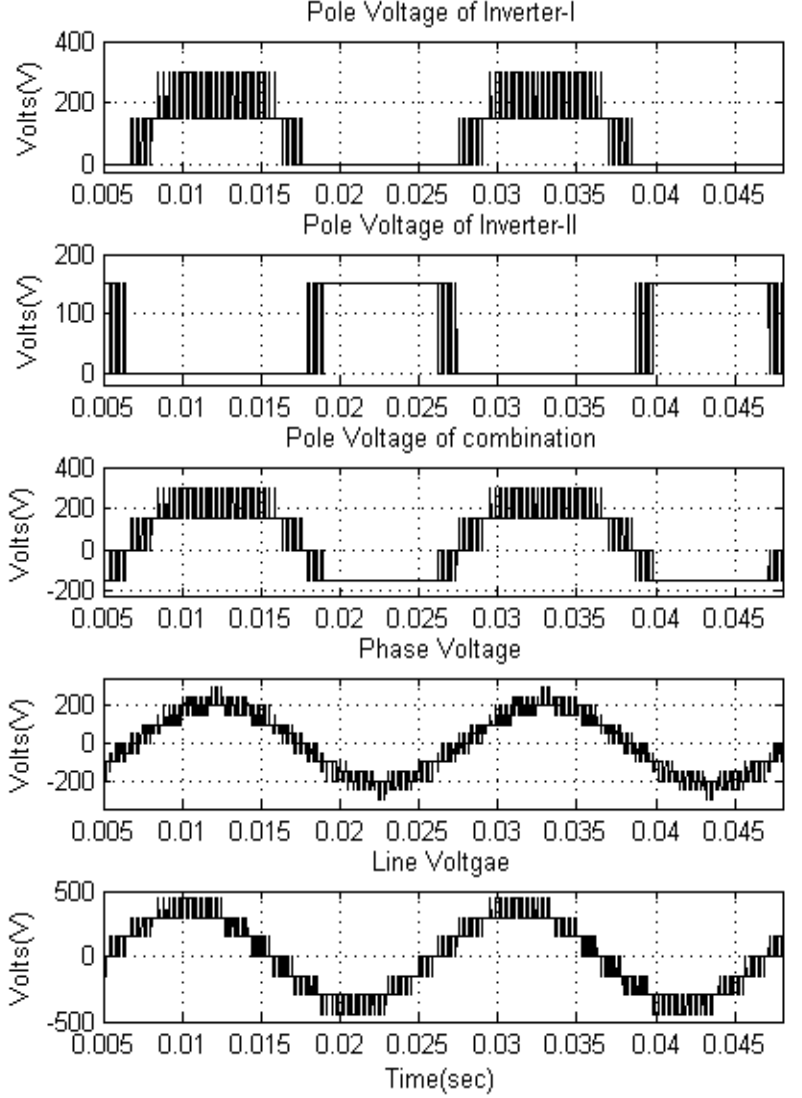

Fig. 11 Voltage plots with DPWMMAX algorithm during fourlevel operation
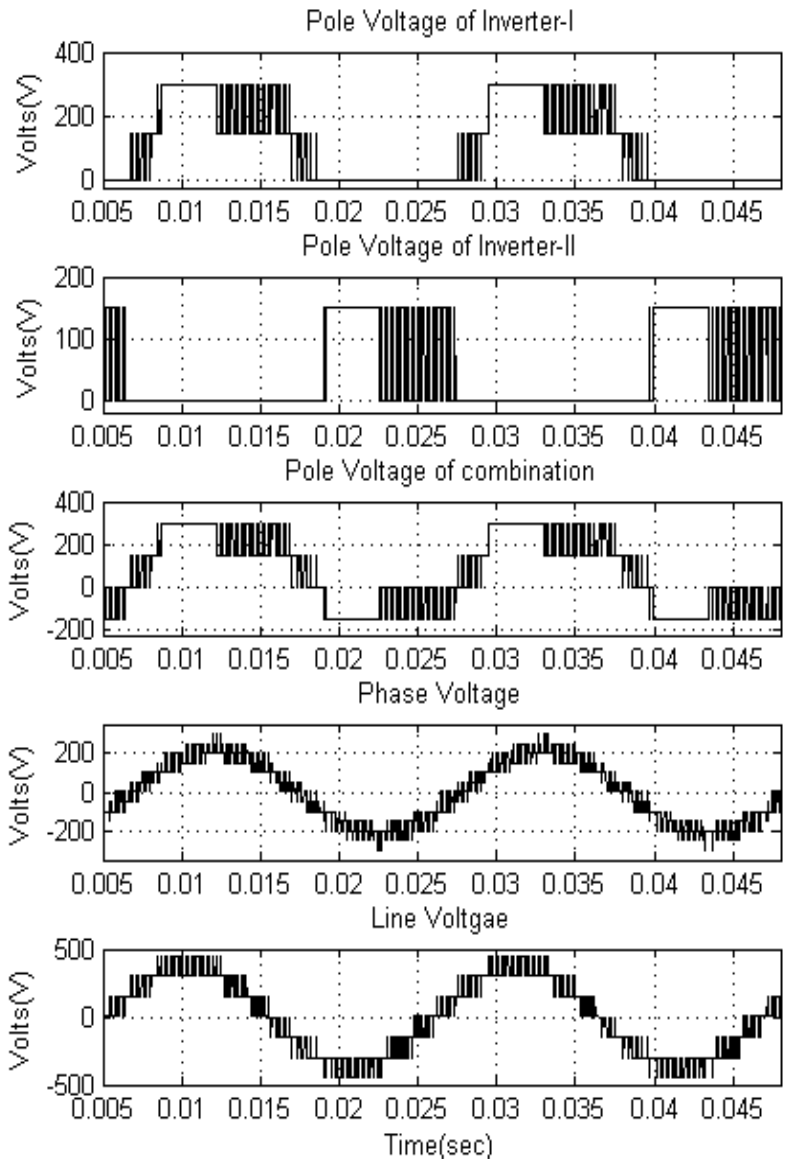

Fig. 12 Voltage plots with DPWM0 algorithm during four-level operation

ISSN 1338-3957 (online), www.aei.tuke.sk 

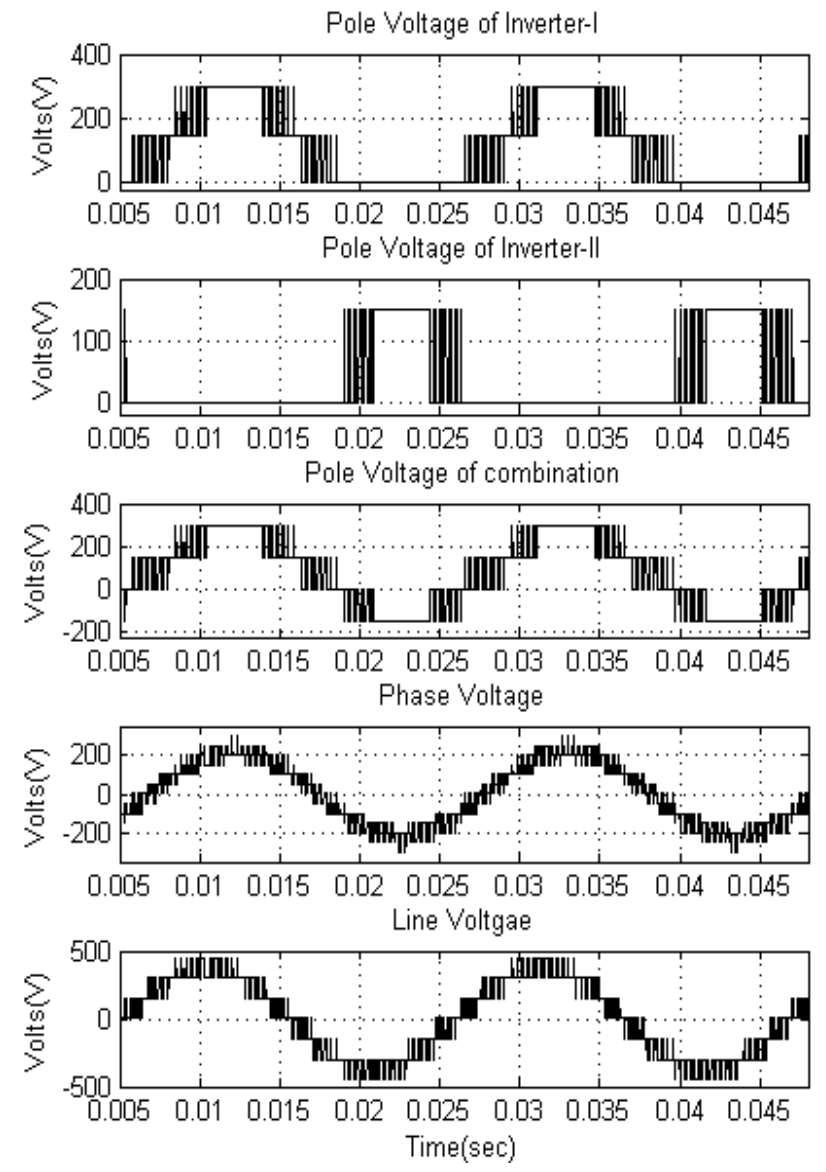

Fig. 13 Voltage plots with DPWM1 algorithm during four-level operation
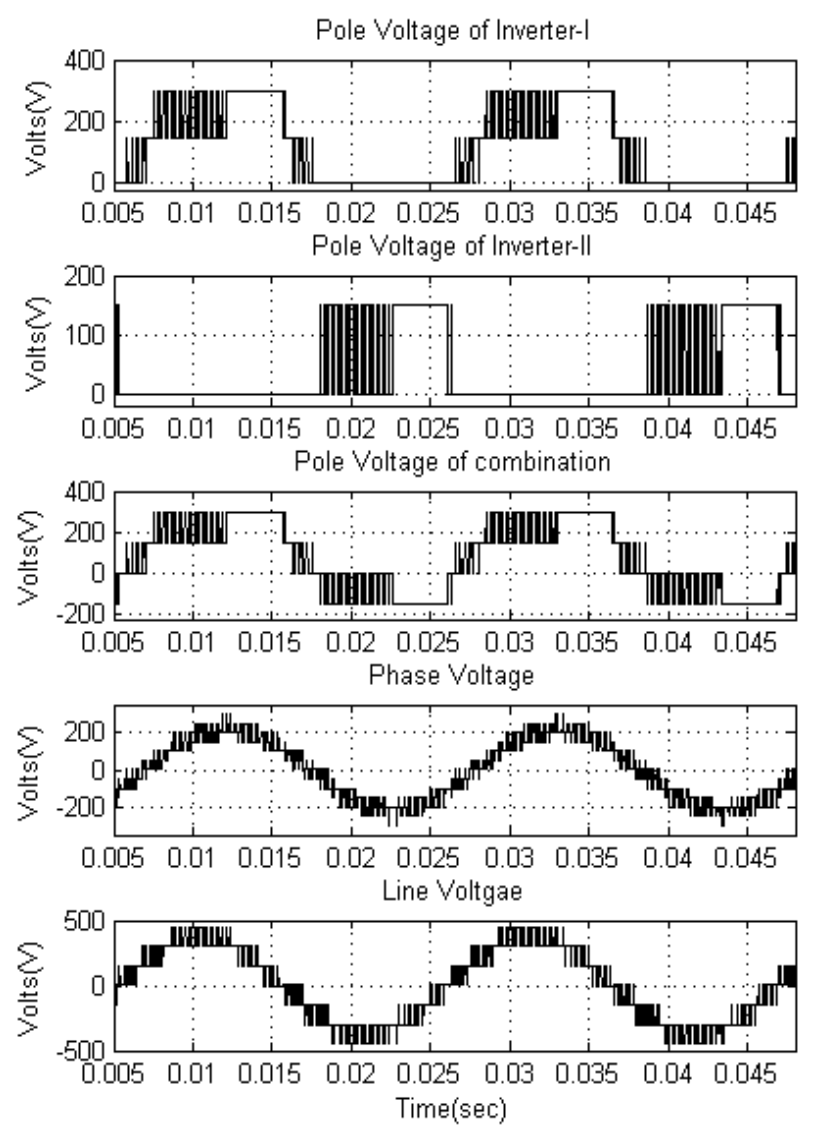

Fig. 14 Voltage plots with DPWM2 algorithm during four-level operation
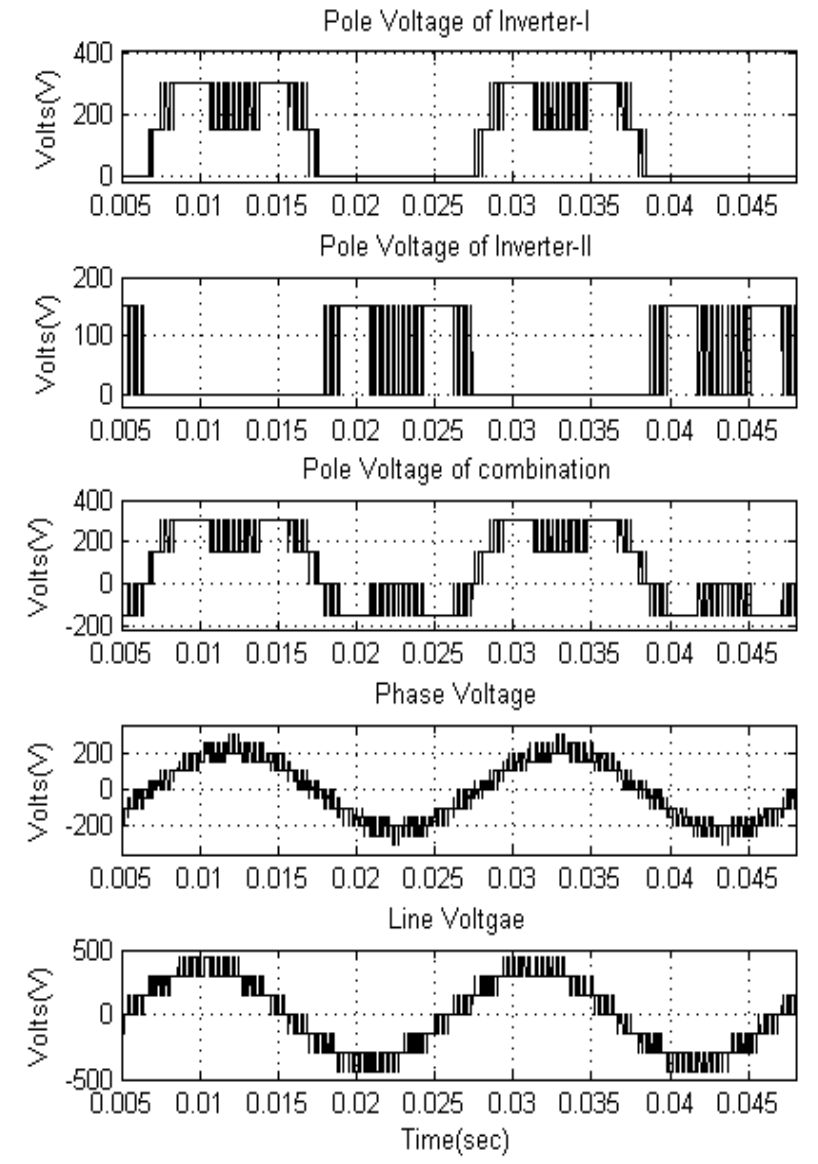

Fig. 15 Voltage plots with DPWM3 algorithm during four-level operation

The harmonic spectra of line voltages for various PWM algorithms are shown in from Fig. 16 to Fig. 23 for four-level operation. Moreover, the harmonic spectra line voltage for two-level and three-level operation with SPWM algorithm is shown in Fig. 24 and Fig. 25. From the harmonic spectra results, it can be observed that as the number of levels increases, the harmonic distortion also decreases. Moreover, the proposed GPWM algorithm gives all possible PWM algorithms with reduced complexity. Also, it can be concluded that as the DPWM algorithms clamp for a total period of 120 degrees in each fundamental cycle, the switching losses can be reduced $33.33 \%$.

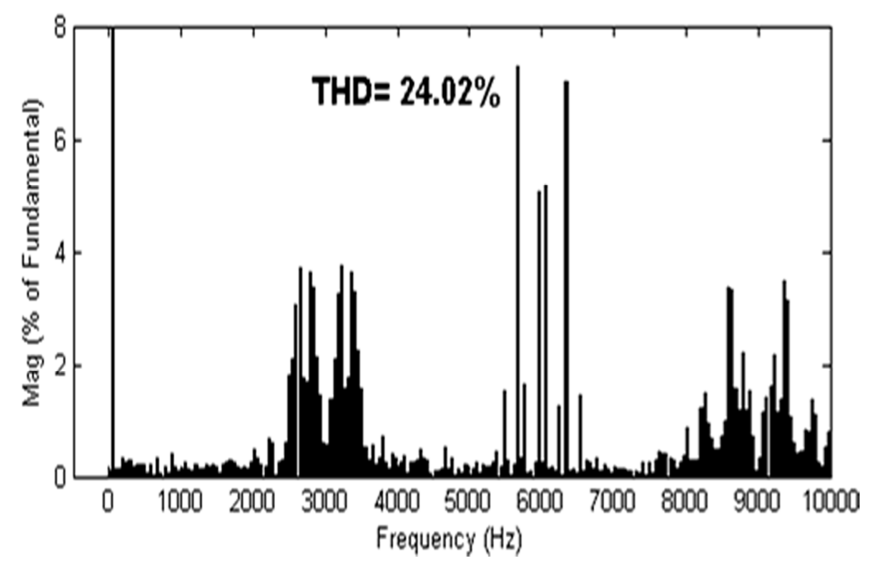

Fig. 16 Harmonic spectra of line voltage for SPWM algorithm 


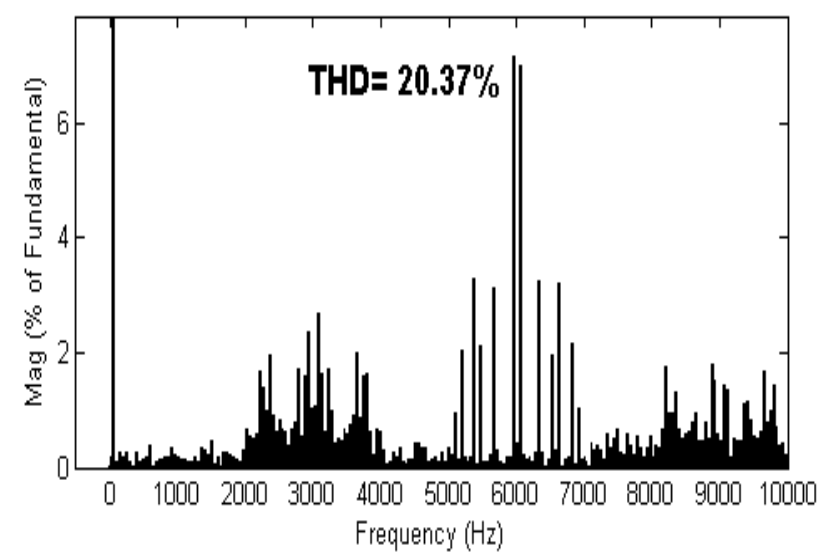

Fig. 17 Harmonic spectra of line voltage for SVPWM algorithm

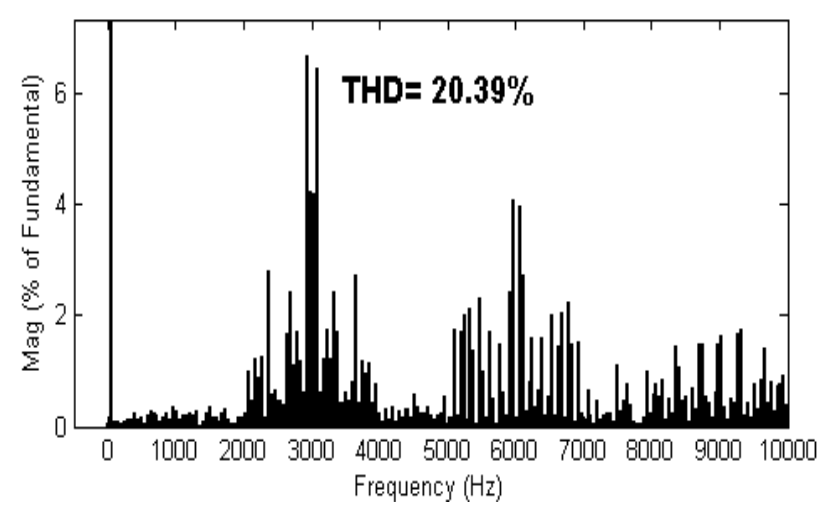

Fig. 18 Harmonic spectra of line voltage for DPWMMIN algorithm

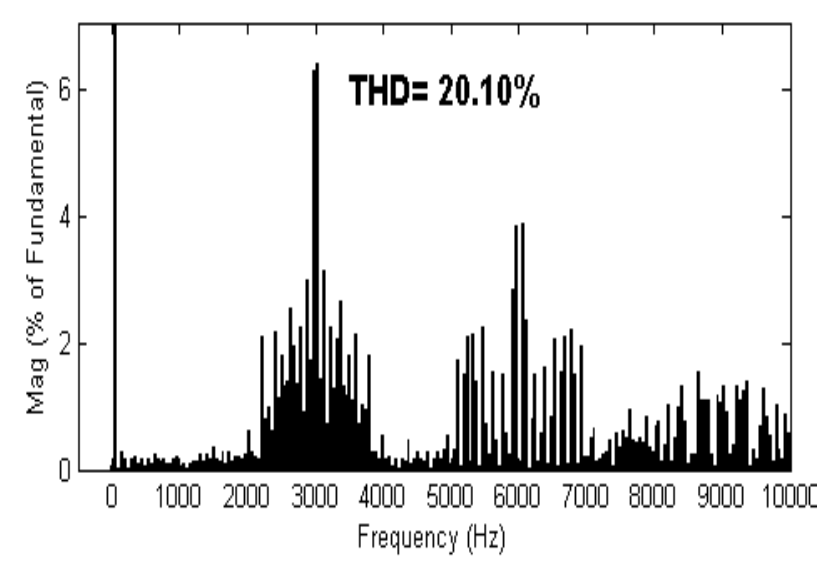

Fig. 19 Harmonic spectra of line voltage for DPWMMAX algorithm

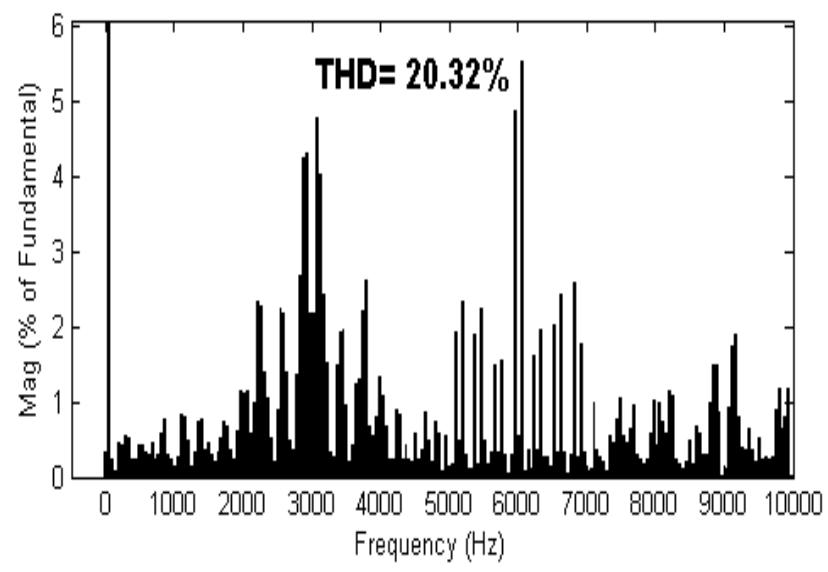

Fig. 20 Harmonic spectra of line voltage for DPWM0 algorithm

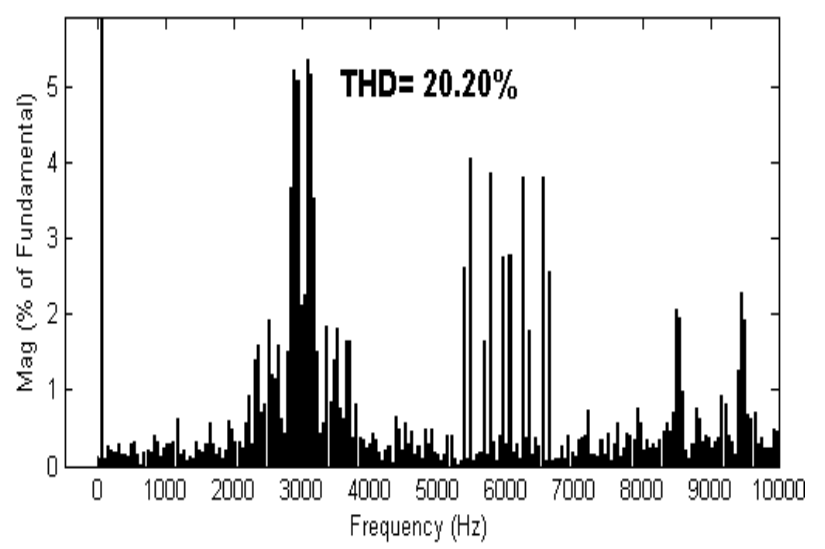

Fig. 21 Harmonic spectra of line voltage for DPWM1 algorithm

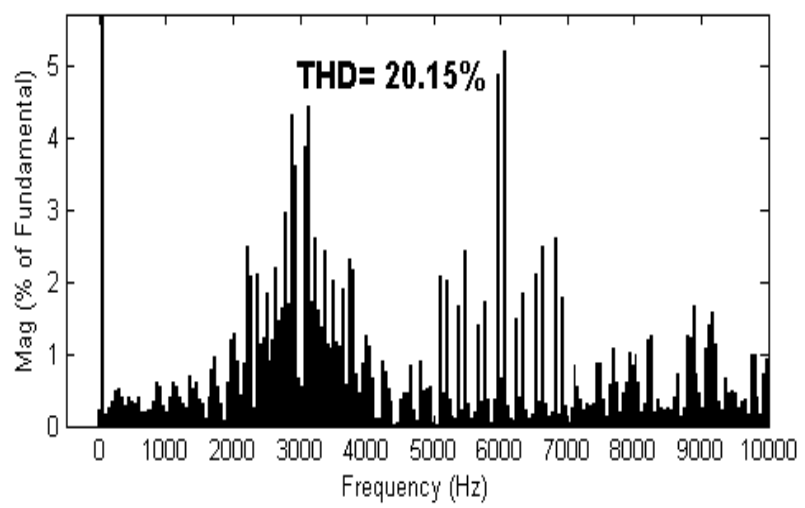

Fig. 22 Harmonic spectra of line voltage for DPWM2 algorithm

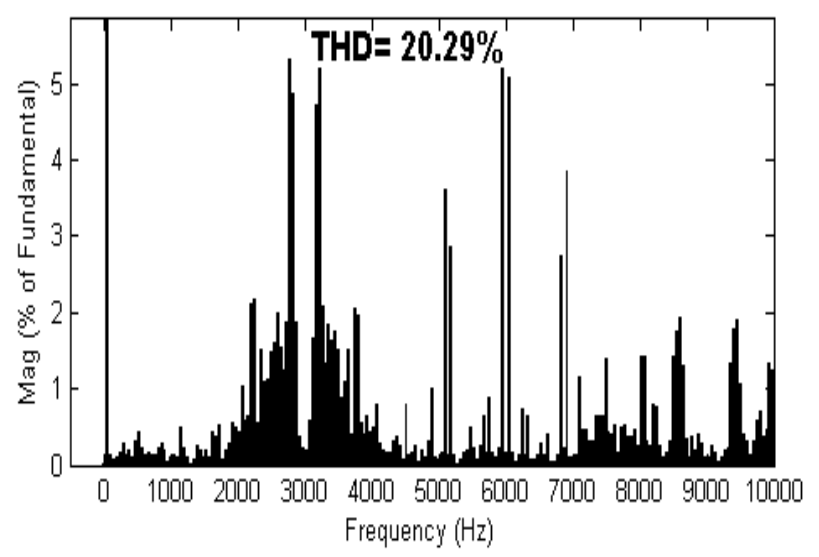

Fig. 23 Harmonic spectra of line voltage for DPWM3 algorithm

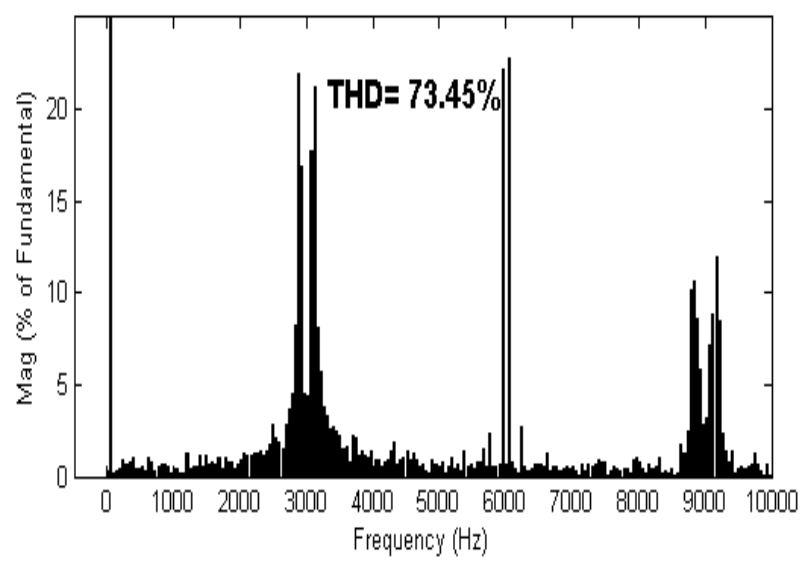

Fig. 24 Harmonic spectra of line voltage for SPWM algorithm for two-level operation. 


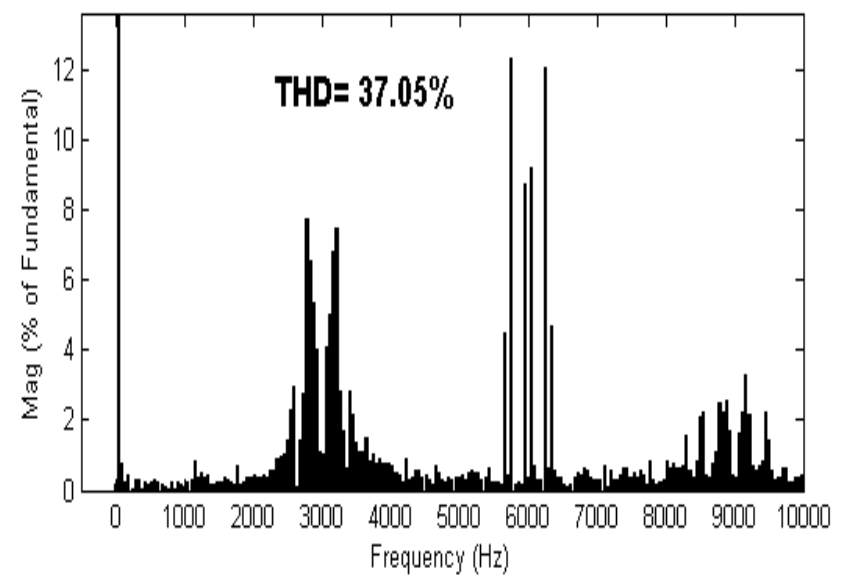

Fig. 25 Harmonic spectra of line voltage for SPWM algorithm for three-level operation.

\section{CONCLUSIONS}

The proposed GPWM algorithm is very simple and is less complex when compared to conventional continuous and discontinuous PWM algorithms. From the results it can be concluded that discontinuous PWM techniques reduce a total of $33 \%$ of switching losses when compared to continuous PWM algorithms. Moreover, the proposed circuit topology can generate two-level, three-level and four-level output voltages with reduced switching losses at all the modulation indices. As number of levels increases harmonic content in the output voltage gets reduced. In view of performance the proposed inverter topology is highly efficient at low voltage rating also. During faulty conditions of the drive the complete motor drive can be operated with one set of inverter by isolating other inverter from the operation.

\section{REFERENCES}

[1] MURPHY, J. M. D. - EGAN, M. G.: A comparison of PWM strategies for inverter fed induction motors, IEEE trans. On Ind. Appl., vol. IA-19, issue. 3, pp. 363-369, May, 1983.

[2] HOLTZ, J.: Pulse Width modulation - A survey, IEEE trans. industrial elec., Vol. 39., pp. 410-420. 1992.

[3] HOLTZ, J.: Pulsewidth modulation for electronic power conversion, Proc. IEEE, vol. 82, no. 8, pp. 1194-1214, Aug. 1994.

[4] VAN DER BROECK, H. W. - SKUDELNY, H. C. - STANKE, G.: Analysis and relisation of pulse width modulator based on voltage space vector, in Proc. IEEE IAS Annu meeting Denver, CO, 1986 pp. 244-251.

[5] KIM, J. S. - KUL, S.: A novel voltage modulation technique of Space Vector PWM, in conf. Rec IPEC -Yokohama'95 pp. 742-747.

[6] VAN DER BROECK, H. W.: Analysis of the harmonics in voltage fed inverter drives caused by PWM schemes with discontinuous switching operation, in Conf. Rec. EPE'91, 1991, vol. 3, pp. 261-266.
[7] CHUNG, D. W. - KIM, J. S. - SUL, S. K.: Unified Voltage Modulation Technique for Real-Time Three-Phase Power Conversion, IEEE Trans industrial appl. Vol. 34, NO. 2, MARCH/APRIL 1998.

[8] HAVA, A. M. - KERKMAN, R. J. - LIPO, T. A.: A high performance generalised discontinuous PWM algorithems, IEEE Trans Ind. Applicat Vol: 34, no. 5 Sep/Oct 1998, pp. 1059-1071.

[9] TEODORESCU, R. - BEAABJERG, F. PEDERSEN, J. K. - CENGELCI, E. - SULISTIJO, S. - WOO, B. - ENJETI, P.: Multilevel converters A survey, in Proc. European Power Electronics Conf. (EPE'99), Lausanne, Switzerland, 1999, CDROM.

[10] RODRÍGUEZ, J. - LAI, J. S.: Multilevel Inverters: A Survey of Topologies Controls and Applications, IEEE Trans. Ind. Ele., Vol. 49, no. 4, pp. 724-737, Aug 2002.

[11] REDDY, T. B. - ISHWARYA, K. - VYSHNAVI, D. - HANEESHA, K.: Generalized Scalar PWM Algorithm for Three level diode clamped inverter fed Induction motor Drive with Reduced complexity, International conf. on APCET, Aug, 2012, India.

[12] SOMASEKHAR, V. T. - GOPAKUMAR, K.: Three-level inverter configuration cascading twotwolevel inverters, IEE Proc.-Eleclr. Power Appl, Vol. 150, No. 3, May 2003.

[13] SHIVAKUMAR, E. G. - GOPAKUMAR, K. SINHA, S. K. - PITTET, A. - RANGANATHAN, V. T.: Space vector control of dual inverter fed openend winding induction motor drive, EPE J., vol. 12, no. 1, pp. 9-18, Feb. 2002.

[14] SOMASEKHAR, V. T. - GOPAKUMAR, K. BAIJU, M. R. - MOHAPATRA, K. K.: A Multilevel Inverter system for an Induction Motor with Openend Winding, in Proceedings of .IEEE IECON 2002 pp. 973-978.

[15] SOMASEKHAR, V. T. - GOPAKUMAR, K. BAIJU, M. R. - MOHAPATRAAND, K. K. UMANAND, L.: A Multilevel Inverter System for an Induction Motor With Open-End Windings, IEEE trans, onindustrial elec. Vol. 52, NO. 3, June 2005.

Received December 6, 2013 , accepted March 17, 2014

\section{BIOGRAPHIES}

M. Harsha Vardhan Reddy received B.Tech degree from Rajeev Gandhi Memorial college of Engineering and Technology, Nandyal, Andhra Pradesh in 2009. He received M.Tech degree in power electronics and drives from Karunya University, Coimbatore in 2011. Currently, he is with G. Pulla Reddy Engineering college, kurnool, as an Assistant Professor. His areas of interests are power electronic control of drives. 
Dr. T. Brahmananda Reddy graduated from Sri Krishna Devaraya University, Anantapur in the year 2001. He received M.E degree from Osmania University, Hyderabad, India in the year 2003 and Ph.D from J.N.T.University, Hyderabad in the year 2009. He is presently working as Professor and Head of Electrical and Electronics Engineering Department, G. Pulla Reddy Engineering College (Autonomous), Kurnool, India. He presented more than 100 research papers in various national and international conferences and journals. His research area includes $\mathrm{PWM}$ techniques, $\mathrm{DC}$ to $\mathrm{AC}$ converters and control of electrical drives.

B.Ravindranath Reddy obtained his B.Tech degree in Electrical \& Electronics Engineering from the J.N.T.U. College of Engg., Anantapur in the year 1991. He obtained his M.Tech degree in Energy Systems from IPGSR of J.N.T.University Hyderabad in the year 1997.
He obtained his doctoral degree from JNTUA, Anantapur University in the field of Electrical Power Systems. He is presently working as Executive Engineer in JNTUH. He has more than 20 research papers. His areas of interests are Power Systems, High Voltage Engineering and Control Systems. His research area includes Simulation studies on Transients of different power system equipment.

M. Surya Kalavathi obtained her B.Tech degree from S.V.University in the year 1988 and M.Tech degree from same university in the year 1992. Obtained her doctoral degree from JNTU, Hyderabad and post doctoral from CMU, USA. She is presently working as professor in JNTU college of Engg. Hyderabad. She has published more than 40 research papers. Her research area includes simulation studies on transients of different power system equipment. 